\title{
Scientific Inquiry and Review (SIR)
}

Volume 2, Issue 4, October 2018

ISSN (P): 2521-2427, ISSN (E): 2521-2435

Journal DOI: https://doi.org/10.32350/sir

Issue DOI: https://doi.org/10.32350/sir.24

Homepage: https://ssc.umt.edu.pk/sir/Home.aspx

Journal QR Code:

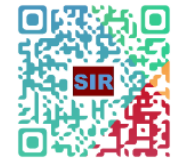

Article:

Author(s):

Online

Published:

Article

DOI:

Article QR

Code:

\section{Fruit Pest Management in Pakistan: A Review}

Sadia Sidra Aziz

Mubashar Hussain

October 2018

doi.org/10.32350/sir.24.05

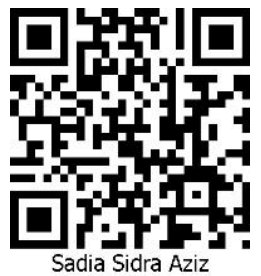

Indexing Agency

Crossref

U L R I C H'S PERIODICALS DIRECTORYM

(1) OCLC 5) WorldCat

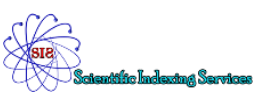

GENERALIMPACTFACTOR

INDEX COPERNICUS

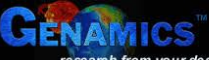

Geresearch from your deskto
Genamics Journal Seek

गIIt Directory of Research

DRJI Journals Indexing

$\mathrm{R} \partial \mathrm{AD}=$ 1). Academic \begin{tabular}{c} 
Resource \\
Index \\
\hline ResearchBib
\end{tabular}

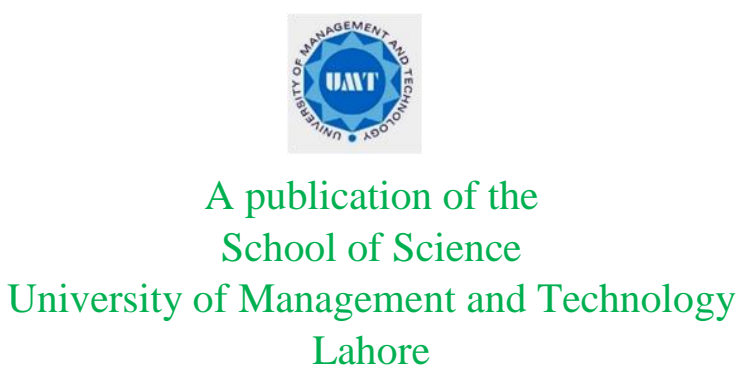

A publication of the

School of Science

Lahore 


\title{
Fruit Pest Management in Pakistan: A Review Sadia Sidra Aziz ${ }^{*}$ Mubashar Hussain $^{2}$ \\ ${ }^{1,2}$ Department of Zoology, University of Gujrat, Gujrat, Pakistan. \\ *sadia.sidra.aziz@gmail.com
}

\begin{abstract}
The purpose of this article is to review several techniques being employed to control various pest species of fruit crops in Pakistan. Fruit pests cause considerable damage to Pakistan's economy as fruit crops contribute approximately $13 \%$ in the GDP of Pakistan. Fruit exports of Pakistan reach up to 2366.5 billion rupees. Unfortunately, major portion of these crops is lost annually because of pre-harvest or post-harvest pest infestations. Fruit flies, citrus whiteflies, cloudywinged whitefly, citrus blackfly, citrus leafminer, Nile whitefly, Pepper whitefly, common walkingsticks, gall midge, mealy bugs, moths and aphids are most important pest species that infest various fruit crops e.g. mangoes, citrus, grapes, guava, peach, apple, date palm, banana, etc. in Pakistan. Fruit flies pose biggest threat as they infest more than 50 fruit crops. Pest control strategies practiced in the country include physical methods e.g. traps, baits, bands, etc.; botanical control, i.e. using plant extracts to which pests are attracted and then killed or plant-based pest repellents; chemical control involving several types of insecticides, pesticides etc. Recently integrated pest management techniques are emerging as successful and eco-friendly method involving all the available measures to cope with a wide range of pest species e.g. plant-based insecticides, traps and baits, mechanical and cultural methods, male annihilation technique (MAT), sterile insect techniques (SIT) etc.; but these techniques have certain limitations too. Therefore, the need arises to continuously work for the betterment of existing pest management techniques and proposing new innovative methods to minimize pest infestations and yield losses in fruit crops.
\end{abstract}

Keywords: fruit crops, pests, integrated pest management, insecticides, MAT, SIT

\section{Introduction}

Pakistan has been blessed with a fertile land that makes agriculture one of the major driving forces of progress in the country [1]. Being an agricultural country, Pakistan earns a lot through the export of fruits mainly mangoes, banana, citrus, guava, grapes, dates, apple etc. [2]. Therefore, the production of fruits holds a considerable portion in the economy of Pakistan. Currently, fruit plants are cultivated over a cumulative area of 7,76,000 hectares with a total production of 6432.9 thousand tons. During the year 2013-2014, fruit export contributed 2,366.5 billion rupees in

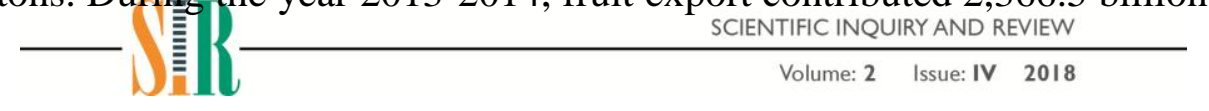


the national economy of Pakistan [3]. Unfortunately, due to unavailability of proper marketing system, $30-40 \%$ of the product turns to waste before even reaching the consumers [4]. About $78 \%$ of the total fruit export of the country is contributed only by dates, mango and citrus. Pakistan holds $6^{\text {th }}$ position in the production of dates and mangoes and stands $20^{\text {th }}$ in the production of apple [5].

\begin{tabular}{|clcccc|}
\hline Fruits & Area/production & $\mathbf{1 9 7 1 - 8 0}$ & $\mathbf{1 9 8 1 - 9 0}$ & $\mathbf{1 9 9 1 - 0 0}$ & $\mathbf{2 0 0 1 - 1 0}$ \\
\hline \multirow{2}{*}{ Citrus } & Area & 7.12 & 6.12 & 1.33 & -0.02 \\
& Production & 6.93 & 5.46 & 1.9 & 1.26 \\
\hline \multirow{2}{*}{ Mango } & Area & 0.36 & 3.76 & 0.97 & 6 \\
& Production & 0.58 & 3.43 & 1.91 & 6.43 \\
\hline \multirow{2}{*}{ Date } & Area & 2.25 & 5.62 & 6.24 & 1.43 \\
& Production & 2.34 & 3.77 & 7.28 & -1.41 \\
\hline \multirow{2}{*}{ Apple } & Area & 9.9 & 6.99 & 8.53 & 6.73 \\
& Production & 11.5 & 8.02 & 4.5 & -1.79 \\
\hline
\end{tabular}

Figure 1. Average decade-wise production of some important fruits in Pakistan [6]

Pests are the organisms that cause several diseases in plants using them as food resulting in decreased yield [7]. Arthropods are responsible for an annual 18$26 \%$ loss of fruit crops worth approximately 470 Billion USD worldwide [8]. Annually over 200 million USD are lost in Pakistan because of fruit flies only [9].

For the effective management and eradication of fruits' pests, continuous and accurate assessment of the population size, including both larvae and adult population is of utmost importance [10]. The development of new pest management strategies with maximum efficiency and minimum hazards associated, is the utmost necessity for increased yield of fruit crops. The present article reviews various pest management strategies employed for the efficient management of the pest species.

\section{Most Important Fruit Pests in Pakistan}

Procontarinia mangiferae (Diptera: Cecidomyiidae) are widely distributed worldwide and are notorious for mango infestation [11]. Out of the many important fruit pests, fruit fly (Bactrocera zonata; Diptera: Tephritidae) is considered as most important economically as it effects about 50 fruit species e.g. peach, custard apple, mango, date palm, citrus, banana, permission, batsch etc.; although it prefers guava mostly [12, 13]. Citrus whiteflies (Dialeurodes citri), cloudywinged whiteflies (Aleurotuberculatus citrifolii), citrus blackfly (Aleurocanthus husaini), citrus leafminer (Phyllocnistis citrella), Nile whitefly (Aleurolobus niloticus), Aleurocanthus woglumi, A. jasmine, Amurrayae, Pepper whiteflies (Aleurotrachelus spp.) and common walkingsticks (D. elongate) are involved in the infestation of citrus fruits [14]. Diaphorina citri (Homoptera) is found widely in 
Sadia Sidra Aziz et al.

areas where citrus is grown [15]. Mealy bugs and fruit flies are recognized as important pests of mangoes [16]. Aphid are known for their infestation of peach [17].

\section{Pest Management Techniques}

In Pakistan, many pest management techniques are in practice depending upon the nature and kind of fruit crop and pest species. Some of them are described as follows.

\subsection{Botanical Control}

Several plants provide us with a variety of extracts that are effective against many species of pests [18]. Leaf extracts from plants including Thevetia peruviana, Cassia fistula, Azadirachta indica, Ocimum basilicum, Datura alba and Eucalyptus camaldulensis provide repellency up to $84 \%$ and decreased pupal growth [19]. Extracts of plants from Pakistan's Northern areas e.g. Eucalyptus sideroxylon, Isodon rugosus, Cinnamomum camphora, Calotropis procera, Boenninghausenia albiflora, Tagetes minuta and Daphne mucronate provide repellence, deterrent oviposition and high mortality in adult specimens of various pest species [20]. Turmeric extract solution in a range of organic solvents e.g. ether, ethanol, acetone etc. causes growth inhibition and repellence in B. zonata [21, 22]. Many insects are attracted towards some organic compounds such as methyl eugenol and few phenylpropanoid compounds, found naturally in various species of plants [23]. Extracts derived from species e.g. Azadirachta indica, Peganum harmala, Acorus calamus, Curcuma longa, Valeriana jatamansi Jones and Saussurea lappa have proven to be effective against a wide variety of insects [5].

Essential oils derived from plants have few compounds such as phenols, terpenes, etc. that are reputed to be efficient insect repellents [17]. Extracts of $A$. indica elicits repellence, antifeeding effects, etc. in Oriental fruit fly species [24]. Bio pesticide derived from neem tree shows effective repellence against $D$. citri spp. [25]. Organic solutions of turmeric extracts contain turmerons e.g. alpha and beta termerons etc. that are highly effective in terms of repellency and mortality rate [26]. Methyl eugenol is used for the monitoring and suppression of pest populations [27].

\subsection{Chemical Control}

Chemical control methods are most common measure for pest management in Pakistan [28]. Pesticide usage was started in 1952 in the country [29] and has reached up to 25 thousand metric tons in 2006 [30]. Most commonly used pesticides belong to pyrethroids, organophosphates and organochlorine e.g., fenvalerate, mevinphos dimethoate, fenitrothion, endosulfan, deltamethrin, chlorpyriphos, methyl parathion dicofol, cypermethrin, profenofos and dichlorvos [31]. Diazinon,

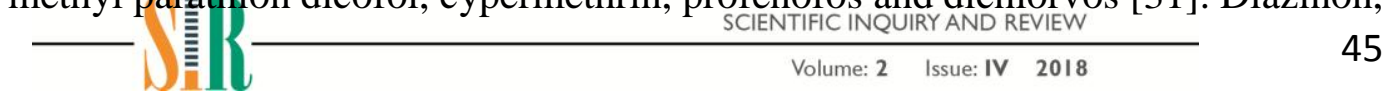


Endrin, Dimecron, Diptrex, and Dialordin as well as pyrethorids organophosphates and carbamates are effectively used against mango, peach, melons, banana, guava, apricot, plum, persimmon etc. [32]. For the infestation of fruit flies, Metasystox, Dipterex, Folidol, Nogos and Dimecron are generally employed [33].

However synthetic insecticides are less preferred now because of the adversaries associated with them e.g. issues related to international trade, poisonous residues that insecticides leave inside fruits and environmental damage [34]. Also, the increased insecticides' usage is associated with insecticide resistance. For example, specimens of $B$. zonata are being increasingly resistant to commonly used insecticides such as malathion, lambda-cyhalothrin, trichlorfon, bifenthrin, spinosad and methomyl etc. [35].

\subsection{Integrated Pest Management}

Insect pest management (IPM) refers to a collaborative approach involving all the available and possible measure to reduce the population of various insect in order to avoid the usage of harmful insecticides to the risk level. IPM techniques has been devised to suppress the increasing use of insecticides because of hazards associated with them. IPM techniques are effective, environmental friendly and reduce infestations [36]. IPM techniques haves been effective in controlling fruit fly infestation up to $17 \%$ in guava orchids [37].

Burying after burning treatment, Burlap and sticky bands, Methyl eugenol traps and stem injection have proven to be highly effective against fruit flies and mealy bugs infestation in mangoes [16]. Techniques such as Male Annihilation Technique (MAT), cultural control and Bait Application technique (BAT) are proven to be effective against oriental fruit fly [38].

Infestation of mango fruit by gall midgets is dealt by using sticky traps of various colors and by the applying the extract of seed kernel derived from neem tree [11]. The mechanical/cultural technique of IPM involves sanitation of the fields. In this process fruits infested with maggots are collected and then buried 46 inches deep in the soil for the destruction of maggots [39].

A newly introduced technique called sterile insects technique (SIT) has many benefits e.g. it is eco-friendly, can be used over many pests, reduces growth rate by producing large number of sterile males using radiations commonly that introduce reproductive failure in their mates [40]. Gamma radiations alter the anatomy, morphology and development of gonads in fruit flies. These radiations cause decreased egg hatching and adult emergence, decreased size and sex ratio and total sterility of eggs [41]. 
Sadia Sidra Aziz et al.

However, IPM techniques have certain limitations too. For example, the mechanical/cultural technique is not suitable because of cost ineffectiveness as it is not possible to bury all the infested fruit because of high labor costs [39]. The use of predators and parasites have proven inefficient because of high fecundity of fruit flies than parasitoids and the poor searching abilities of the latter for pupal and larval populations of the target species [42].

\section{Conclusion}

For obtaining maximum yields from fruit crops, efficient management of pest species is of utmost importance. Therefore, there is a continuous need for advancements in pest management strategies because of the increasing pesticide resistance. Integrated pest management strategies are at an increased advantage over conventional insecticidal usage because of effective reduction in population size and pest repellency; environmental friendliness, no residual compounds in fruits etc.

For pest management strategies to become successful, area-wise population assessment of prevailing insects is mandatory. It is beneficial to study the habitats preferences, feeding habits and behavior patterns of pests to devise efficient control strategies. Investigations are necessary for the separation and identification of active compounds in plant extracts, insecticides, pesticides etc. in order to use these compounds efficiently. Techniques should be developed to control increasing pesticide resistance in insects, together with the prevention of indiscriminate pesticide usage. It should be ensured that consumers are not eating fruits containing pesticide residues. For this purpose, innovative methods such as gene manipulation to reduce the reproductive capabilities of the pest species are required to overcome the limitations of IPM techniques.

\section{References}

[1] Government of Pakistan, Ministry of Industries and Production, Small \& Medium Enterprise Development Authority (SMEDA). Regulatory procedure for export of horticulture from Pakistan. Islamabad: SMEDA; 2010.

[2] Anonymous. Food and Agricultural Organization, Statistics Division. 2010.

[3] Government of Pakistan, Finance Division, Economic Advisor's Wing. Pakistan Economic Survey 2013-14. Islamabad: Economic Advisor's Wing; 2014.

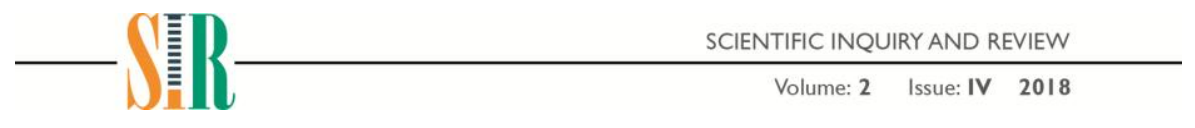


Fruit Pest Management in Pakistan

[4] Government of Pakistan, Finance Division, Economic Advisor's Wing. Pakistan Economic Survey 2006-07. Islamabad: Economic Advisor's Wing; 2007.

[5] Akhtar N, Jilani G, Mahmood R, Ashfaque M, Iqbal J. Effects of plant derivatives on settling response and fecundity of peach fruit fly Bactrocera zonata (Saunders). Sarhad J Agric. 2004;20:269-274.

[6] Nazir M, Akhtar W, Akmal N, Batool S. (2016). Export forecasting of major fruit crops of Pakistan. Sci Technol Dev. 2016;35(4):148-152.

[7] Ata S, Wattoo HF, Feroz M, Wattoo SHM, Tirmizi AS, Asad JM. Analytical investigation of selected pesticide residues from fruits and vegetables by an improved extraction method using reverse phase high performance liquid chromatography. Ethiopian $J$ Environ Stud Manage. 2015;6(4):342-347.

[8] Culliney WT. Crop losses to arthropods. Integr Pest Manage Rev. 2014;3:201-225.

\section{$\underline{\text { Crossref }}$}

[9] John MS, Mumford JD, Mustafa G. Economics losses of tephritid fruit flies (Diptera: Tephritidae) in Pakistan. Crop Prot. 1997;17(2):159-164.

[10] Sarwar M. Occurrence of insect pests on guava (Psidium guajava) tree. Pakistan J. Zool. 2006;38(3):197-200.

[11] Rehman MH, Mehmood R, Razzaq M, Reddy PVG. Damage patterns, monitoring, and management of procontarinia mangiferae (Diptera: Cecidomyiidae) in Pakistan. $J$ Econ Entomol. 2016;109(6):2446-2453.

\section{Crossref}

[12] Awad AA, Ali NA, Mohamed HO. Ultrastructure of the antennal sensillae of male and female peach fruit fly, Bactrocera zonata. $J$ Insect Sci. 2014;14(45):1-15.

\section{Crossref}

[13] Syed RA, Ghani MA, Murtaza M. Studies on the trypetids and their natural enemies in West Pakistan. III. Dacus (Strumeta) zonatus (Saunders). Tech Bull, Commonw Inst Bio Control. 1970;3:1-16. 
[14] Mahmoud R, Rehman A and Ahmed M. Prospects of biological control of citrus insect pests in Pakistan. $J$ Agric Res. 2014;52(2):229-244.

[15] Khan AA, Afzal M, Raza MA, Khan MA, Iqbal J, Tahir MH, et al. Toxicity of botanicals and selective insecticides to Asian citrus psylla, Diaphorina citri K. (Homoptera: Psyllidae) in laboratory conditions. Jokull J. 2013; 63(8):52-72.

[16] Ishaq M, Usman M, Asif M, Khan IA. Integrated pest management of mango against mealy bug and fruit fly. Int J Agri Biol. 2004;6(3):452-454.

[17] Isman BM. Plant essential oils for pest and disease management. Crop Prot. 2000; 19(2000):603-608.

\section{Corssref}

[18] Isman MB. Botanical insecticides, deterrents, and repellents in modern agriculture and an increasingly regulated world. Апnи Rev Entomol. 2006;51:45-66.

\section{Crossref}

[19] Ilyas A, Khan AAH, Qadir A. Effect of essential oils of some indigenous plants on settling and oviposition responses of peach fruit fly, Bactrocera zonata (Diptera: Tephritidae). Pakistan J Zool. 2017;49(5):1547-1553.

\section{Crossref}

[20] Khan S, Shah MM, Ahmed R, Haq I. The insecticidal potential of botanical extracts for management of Peach fruit fly, Bactrocera zonata Saunders, 1842 (Diptera: Tephritidae). Türk Entomol Derg. 2016;40(4):445-453.

\section{$\underline{\text { Crossref }}$}

[21] Riaz RM, Rauf AS, Rafi AM, Jilani G, Siddiqi RA. Potential of turmeric extract and its fractions to control peach fruit fly (Diptera: Tephritidae). Ciênc Agrotec Lavras. 2015;39(6):545-552.

\section{Crossref}

[22] Siddiqi AR, Jilani G, Rehman JU, Kanvil S. Effect of turmeric extracts on settling response and fecundity of peach fruit fly (Diptera: Tephritidae). Pakistan J Zool. 2006;38:131-135.

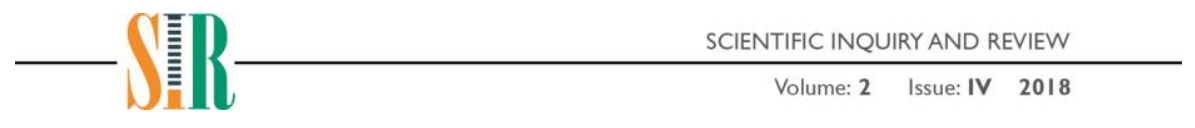


[23] Nishida R, Tan KH. Methyl eugenol: Its occurrence, distribution, and role in nature, especially in relation to insect behavior and pollination. J Insect Sci. 2012;12(56):1-74.

\section{$\underline{\text { Crossref }}$}

[24] Shivendra S, Singh RP. Neem (Azadirachta indica) seed kernel extracts and azadirachtin as oviposition deterrents against the melon fly (Bactrocera cucurbitae) and the oriental fruit fly (Bactrocera dorsalis). Phytoparasitica. 1998;26:191-197.

\section{Crossref}

[25] Isman MB. Neem and related natural products. In: Hall FR, Menn JJ. (eds.). Biopesticides: Use and delivery, methods in Biotechnology, vol 5. New York: Humana Press; 1999. p.139-153.

[26] Mostafa TS. Effect of certain plant extracts on body weight and some biochemical aspects of the khapra beetle, Trogoderma granarium Everts. Bull Entomol Soc Egypt. 1993;20:77-85.

[27] Steiner LF, Hart WG, Harris EJ, Cunningham RT, Ohinata K, Kamakahi DC. Eradication of the oriental fruit fly from the Mariana Islands by the methods of male annihilation and sterile insect release. J Econ Entomol. 1970;63:131-135.

\section{$\underline{\text { Crossref }}$}

[28] Stonehouse JM, Mumford JD, Mustafa G. Economic losses to tephritid fruit flies (Diptera: Tephritidae) in Pakistan. Crop Protect. 1997;17(2):159-164.

\section{Crossref}

[29] Tariq MI, Afzal S, Hussain I, Sultana N. Pesticides exposure in Pakistan: A review. Environ Intl. 2007;33:1107-1122.

\section{Crossref}

[30] Anonymous. Pakistan Horticulture Development \& Export Board (PHDEB). Ministry of Commerce, Government of Pakistan, Islamabad. 2007.

[31] Anwar T, Ahmed I, Tahir S. Determination of pesticide residues in fruits of Nawabshah District, Sindh, Pakistan. Pak J Bot. 2011;43(2):1133-1139. 
[32] Integrated pest management model for fruit flies. In: A Rashid, $M$ Afzal, Z Ahmad. (eds.). PARC in service of nation: Research based knowledge and technologies. Islamabad: Pakistan Agriculture Research Council; 2006. p. 40-41.

[33] Roush RT. Inheritance and effective dominance of pyrethroid resistance in the horn fly (Diptera: Muscidae). J Econ Entomol. 1986;79(5):1178-1182.

\section{Crossref}

[34] El-Aw MAM, Draz KAA, Hashem AG, El-Gendy IR. Mortality comparison among Spinosad-, Actara-, Malathion-, and Methomylcontaining baits against peach fruit fly, Bactrocera zonata (Saunders) (Diptera: Tephritidae) under laboratory conditions. $J$ Appl Sci Res. 2008;4:216-223.

[35] Nadeem KM, Ahmed S, Nadeem S, Ishfaq M, Fiaz M. Assessment of insecticides resistance in field population of Bactrocera zonata (saunders) (Diptera: Tephritidae). $J$ Anim Plant Sci. 2014;24(1):172-178.

[36] Ketelaar JW, Kumar P. Vegetable integrated production and pest management: The case for farmers as IPM experts. International Conference on Vegetables, 1-14 November 2002, Bangalore, India.

[37] Khan MM, Shah HWS, Akhter I, Malik H. Integrated pest management of fruit flies in guava orchids. J Entomol Zool Stud. 2017;5(2):135-138.

[38] Ali H, Ahmed S, Jan S, Saifullah. Efficacy of different control methods against oriental fruit fly Bactrocera Zonata (Saunders). ARPN J Agric Biol Sci. 2010;5(2):1-3.

[39] Panhwar F. Mediterranean fruit fly (Ceratitis capitata) attack on fruits and its control in Sindh, Pakistan. Verlag GmbH, Germany: Digital Verlag; 2005. p. 1-10.

[40] Bakri A, Heather N, Hendrichs J, Ferris I. Fifty years of radiation biology in entomology: Lessons learned from IDIDAS. Ann Entomol Soc Am. 2005;98:1-12.

\section{Crossref}

[41] Mahmoud FM, Barta M. Effect of gamma radiation on the male sterility and other quality parameters of peach fruit fly, Bactrocera

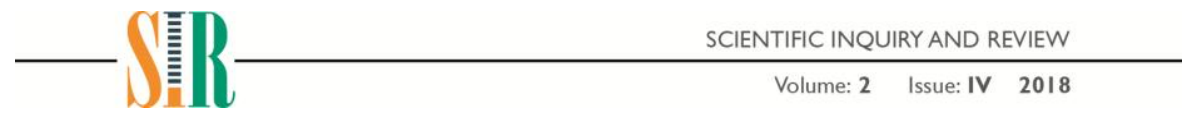


zonata (Saunders) (Diptera: Tephritidae). Hort Sci. 2011;38(2):5462.

\section{Crossref}

[42] Sivinski J. The pest and potential of biological control of fruit flies. DelRay Beach, Florida, USA: St. Lucie press; 1996. p. 369-375. 